MEAN YIELDS OF GRAIN (CWT./ACRE)

\begin{tabular}{|c|c|c|c|c|c|c|c|c|c|}
\hline \multirow{3}{*}{$\begin{array}{l}\text { Treat- } \\
\text { ment }\end{array}$} & \multirow{3}{*}{ App- } & \multicolumn{4}{|c|}{$\begin{array}{l}\text { Spring oats } \\
\text { (var. Star) }\end{array}$} & \multicolumn{4}{|c|}{$\begin{array}{l}\text { Spring barley } \\
\text { (var. Abed Kenia) }\end{array}$} \\
\hline & & \multicolumn{4}{|c|}{$\begin{array}{l}\text { A pplic. rate (lb./acre } \\
\text { acid) }\end{array}$} & \multicolumn{4}{|c|}{ Applic. rate (1b./acre } \\
\hline & & 0 & 1 & 2 & 4 & 0 & 1 & 2 & 4 \\
\hline $\begin{array}{l}n \text {-Butyl } \\
\text { ester of } \\
\text { 'Meth- } \\
\text { oxune' }\end{array}$ & $\begin{array}{l}\text { Early } \\
\text { Late }\end{array}$ & \multirow{2}{*}{$26 \cdot 1$} & $\begin{array}{l}24 \cdot 2 \\
25 \cdot 0\end{array}$ & $\begin{array}{l}24 \cdot 8 \\
23 \cdot 9\end{array}$ & $\begin{array}{l}21 \cdot 8 \\
20 \cdot 5\end{array}$ & \multirow{2}{*}{$30 \cdot 7$} & $\begin{array}{l}29 \cdot 0 \\
31 \cdot 4\end{array}$ & $\begin{array}{l}26 \cdot 1 \\
31 \cdot 1\end{array}$ & $\begin{array}{l}22 \cdot 4 \\
20 \cdot 9\end{array}$ \\
\hline $\begin{array}{l}n \text {-Butyl } \\
\text { ester of } \\
2,4-\mathrm{D}\end{array}$ & $\begin{array}{l}\text { Early } \\
\text { Late }\end{array}$ & & $\begin{array}{l}19 \cdot 6 \\
19 \cdot 1\end{array}$ & $\begin{array}{r}18 \cdot 5 \\
9 \cdot 2\end{array}$ & $\begin{array}{r}14 \cdot 2 \\
9 \cdot 6\end{array}$ & & $\begin{array}{l}27 \cdot 8 \\
21 \cdot 3\end{array}$ & $\begin{array}{l}22 \cdot 0 \\
12 \cdot 8\end{array}$ & $\begin{array}{r}13 \cdot 5 \\
7 \cdot 9\end{array}$ \\
\hline \multicolumn{2}{|c|}{$\begin{array}{l}\text { S.E. (single sub- } \\
\text { plot) } \\
\text { Coeff. of varia- } \\
\text { tion } \\
\text { sig. diff. control } \\
\text { against othcr } \\
\text { treatments } \\
\text { Sig. diff. be- } \\
\text { tween treat- } \\
\text { ments }\end{array}$} & & $1 \cdot 9$ & & & & $\begin{array}{r}2 \cdot 1 \\
8 \cdot 4\end{array}$ & ger cen & \\
\hline
\end{tabular}

Early application: April 28, 1949

Late application: 4 in. high

May 23,1949

May 9, 1949

Barley 6 in. high

Barley 15 in. high

(Papaver rhceas), scentless mayweed (Matricaria inodora), amphibious bistort (Polygonum amphibium), knotgrass (Polygonum aviculare) and black bindweed (Polygonum convolvulus), the $n$-butyl ester of 2 -methyl 4-chlorophenoxyacetic acid formulated as described above proved more effective than an aqueous solution of the sodium salt.

To what extent this difference is due to the ester itself rather than to the other constituents of the emulsion is not yet determined. The results given above, however, clearly indicate that it may be possible to use heavier doses of 2 -methyl 4-chlorophenoxyacetic ester formulations on cereal crops than have so far been feasible with the widely used esters of $2: 4$-dichlorophenoxyacetic acid.

W. G. Templeman

J. O. WRIGHT

Imperial Chemical Industries, Ltd.,

Jealott's Hill Research Station,

Bracknell, Berks.

Sept. 18.

'Templeman, W. G., and Halliday, D. J., Emp J. Exp. Agric., 18, No. $71,169(1950)$

${ }^{2}$ Syncrbolm, M. F., and Zimmerman, P. W., Contr. Boyce Thompson Inst., 14, No. 2, 91 (1945).

\section{A Rapid Method of Leaf Area Determination}

RECENT physiological studies on nutrition and growth have shown that leaf area is a reliable index of growth factors determining dry matter accumulation, carbohydrate metabolism, yield and quality of crops ${ }^{1-9.12}$. Various methods have therefore been devised for measuring the total leaf surface on a growing plant. Of these, mention may particularly be made of : (1) methods based on tracing individual leaves and determining their respective area by planimeter; (2) use of sensitized photopapers, (3) photo-electric devices of various types, (4) adoption of cardboards of known area approximating to the area of different type leaves, and lastly (5) use of mathematical formulie based on certain leaf measurements. The utility of one or the other of these methods has been stressed by different investigators.
Recently, we developed a simple method of estim ating leaf surface in graminaceous plants based on linear measurements of individual leaves. On the basis of such length and width measurements, it was possible to determine the leaf area (one surface only) by the formula :

$$
\log A=\log L+\log B-\log K,
$$

where $L$ is length of leaf, $B$ width of leaf in the middle of foliage, $K$ average leaf factor $\left(\frac{L \times B}{\operatorname{area}}\right)$ calculated previously for a population of leaves.

Use of this formula in barley10,11, maize ${ }^{11,12}$, paddy, sugar-cane and wheat gave an experimental error of $2 \cdot 3,1.9,0.86,0.67$ and 0.048 per cent respectively when the measurements were extended to a population of twenty-two leaves.

The above formula may also be modified as :

$\log \Sigma A=\log \Sigma L+\log \Sigma B-\log K-\log N$,

if only the total leaf area exposed on the entire plant is desired. In this case all other factors remain the same except $N$, which indicates the total number of leaves sampled. The experimental error involved in the use of this formula has been found to vary as follows: barley $2 \cdot 9$, maize $6 \cdot 6$, paddy $3 \cdot 3$, sugarcane $0 \cdot 13$ and wheat $1 \cdot 0$ per cent.

It would therefore appear that the above formula is well suited for biological investigations on growing plants where area is to be determined at successive stages of life-cycle. Its utility in graminaceous plants is established. How far the application of a similar principle to other crops would be helpful is a matter for future investigation.

The method is simple and mechanical. It does not involve separation of leaves. No costly appliances are needed. The entire determination is completed within a short time. It is considered, therefore, to be an important means for determining area in growing graminaceous plants.

\section{K. N. LAL}

M. S. Subba Rao

Plant Physiological Laboratory, College of Agriculture,

Benares Hindu University. Oct. 10.

' Darrow, G. M., Plant Physiol., 7, 745 (1932).

${ }^{2}$ Gerdel, R. W., and Salter, R. M., J. Amer. Soc. Agron., 20, 635 (1928).

3 Goodal, D. W., Ann, Bot. (N.S.) 11, 449 (1947).

4 Gregory, F. G., Ann. Bot., 35 (1921).

${ }^{5}$ Gustafson, F. G., and Elnore, S.: Plant Physiol., 11, 445 (1936).

- Hopkins, J. W., Canad. J. Agric. Res., Sect. Bot., 17, 300 (1939)

${ }^{7}$ Lal, K. N., and Mehrotra, O. N., Proc. Ind. Acad. Sci., B (in the press).

8 Oinone, Y., J. Sci. Agric. Soc., 300, 525 (1927).

'Watson, D. J., J. Agric. Sci., 27, 474 (1937).

${ }^{10} \mathrm{Jal}, \mathrm{K}$. N., and Subba Rao, M. S., Sci. and Culture, 15, 355 (1950). ${ }^{11}$ Lal, K. N., and Subba Rao, M. S. (unpublished data).

${ }^{12}$ Lal, K. N., and Subba Rao, M. S., Current Sci., 19, 179 (1950).

\section{Occurrence of Myxine off the Berwickshire Coast}

The cyclostome Myxine glutinosa Linnæus is generally regarded nowadays as being fairly uncommon off the British coasts, though Meek, in 1916, stated that it was fairly common off the east coast of Scotland. Cole ${ }^{1}$ found the species during 1905-25 in large numbers off Cullercoats, Northumberland; but of recent years there have been few records from that area. 